How to cite this article:

Fong, C. S., \& De Witt, D. (2019). Developing Intercultural communicative competence: Formative assessment tools for Mandarin as a foreign language. Malaysian Journal of Learning and Instruction, 16(2), 97-123.

\title{
DEVELOPING INTERCULTURAL COMMUNICATIVE COMPETENCE: FORMATIVE ASSESSMENT TOOLS FOR MANDARIN AS A FOREIGN LANGUAGE
}

\author{
Chan Suet Fong \& ${ }^{1}$ Dorothy DeWitt \\ ${ }^{\prime}$ Department of General Studies, Polytechnic of Sultan Azlan Shah, \\ Malaysia \\ ${ }^{2}$ Department of Curriculum and Instructional Technology, \\ University Malaya, Malaysia \\ ${ }^{1}$ Corresponding author: dorothy@um.edu.my
}

Received: 13/10/2018 Revised: 28/1/2019 Accepted: 15/4/2019 Published: 24/12/2019

\begin{abstract}
Purpose - Intercultural communicative competence (ICC) is important in intercultural exchange, to address problems and conflicts which may arise due to miscommunication that results from interlocutors' diverse cultural and linguistic backgrounds. Interlocutors may have different perceptions and interpretations of communicative behaviour. However, cultural and intercultural aspects seem to be ignored in teaching Mandarin as a foreign language (MFL) in Malaysian higher education institutions. Hence, the ICC level among local MFL learners is unknown. In this study, formative assessments were designed in a culturally integrated MFL module to investigate learners' level of ICC in a selected Malaysian polytechnic.
\end{abstract}

Methodology - The polytechnic was selected as cultural competency was incorporated in the MFL course. A design and developmental research was carried out to design formative assessment for ICC based on experts' feedback. The assessment comprised Intercultural 
Discussion and Reflections, Cultural Discovery, Cultural Quizzes and an Intercultural Communicative Task. They were implemented to assess learners' ICC.

Findings - The results indicate that different forms of assessment were suitable for assessing the respective competences, and that multiple forms of formative assessment should be employed to assess and improve MFL learners' ICC.

Significance - Instructors in higher education could apply these forms of formative assessment to develop ICC among their MFL learners. The assessments could also be extended to intercultural communication competence development in other languages, which is important in a multicultural and globalized society.

Keywords: Intercultural Communicative Competence (ICC), Mandarin as a foreign language, formative assessment.

\section{INTRODUCTION}

In today's globalized world, foreign language education needs to focus on cultural and intercultural understanding in addition to linguistic knowledge and skills. With increased transnational collaboration and competition, having intercultural communicative competency is an asset. Hence, intercultural communicative competence (ICC) or acquiring the cultural perspectives of the target culture and being sensitive to intercultural aspects between the learners' own culture and others' cultures, is a requirement for foreign language education in many countries (American Council on the Teaching of Foreign Language, 2017; Council of Europe, 2017; The Office of Chinese Language Council International, 2010).

ICC in foreign language studies attempts to avoid the misunderstandings and conflicts common in learning a foreign language (Hammer, 1999). This is because during intercultural communication, interpretations are made based on assumptions and perceptions from the interlocutors' differing cultural background (Kramsch, 1993; Liddicoat, 2001). With ICC, miscommunication can be averted among learners from different cultural and linguistic backgrounds who may have different perceptions and interpretations of communicative behaviour (Bennett, 1993). As linguistic 
competence does not ensure ICC, cultural and intercultural aspects should be made explicit in the foreign language curriculum (Byram, 1997; Deardorff, 2006; Jin, 2013; Kramsch, 1993). The Common European Framework of Reference for Languages (CEFRL) reflects a shift in foreign language education from native-speaker mastery towards plurilingual and pluricultural competence where linguistic and cultural aspects are valued (Council of Europe, 2017). The ICC approach could also increase motivation. A study on learning Spanish as a foreign language in a technical university in Malaysia showed that students were motivated to learn the language when they appreciated the target language and culture (Hou-Keat, Hassan, \& Ramli, 2017).

Malaysia is a multiracial and multicultural society comprising Malays and bumiputra (indigenous) groups (68.8\%), Chinese (23.2\%), Indians (7.0\%) and others (1.0\%) (Department of Statistics Malaysia, 2017). While $75.8 \%(2,033,478)$ of students attend national primary schools with Malay as the medium of instruction, only $20.4 \%(548,079)$ attend national-type Chinese schools where Mandarin is the medium of instruction (Ministry of Education, 2015). For many MFL learners, Mandarin is essentially a foreign language as they do not interact in the language and are not immersed in a Mandarin speaking environment. In Malaysia, Mandarin is neither the national language nor a common language as its usage is only limited to the Chinese community (Wang, 2016).

At the tertiary level, Mandarin as a foreign language (MFL) is offered as an elective course and a minor programme for nonMandarin speakers in higher education institutes (HEIs), i.e., public and private universities, polytechnics and colleges (Hoe, 2014; Yap, 2011). The goal is for graduates to be competent linguistically and culturally, and to be able to interact with Mandarin-speakers for business and work, both locally and internationally.

However, research on cultural elements in the teaching of MFL in HEIs is limited. A survey of 20 local public HEIs showed that the MFL textbooks used lacked cultural information other than on some local festivals (Hoe, 2016). An analysis of elementary level MFL textbooks from seven public HEIs in Malaysia showed little cultural and intercultural elements (Chan, DeWitt, \& Chin, 2018). Further, culturally contextualized vocabulary and elements were found lacking in two sets of MFL textbooks from a local public HEI (Fan, 
2104). These studies indicate that there may be insufficient cultural and intercultural elements in MFL courses in local HEIs, and that ICC among MFL learners is probably low. Hence, resources with cultural and intercultural elements are required for learners in MFL courses (Chan et al., 2018; Fan, 2014).

A Culturally Integrated MFL (CIMFL) module was designed to develop ICC among elementary-level MFL learners at an HEI, comprising resources and formative assessment. Assessments can be used to develop ICC (Deardorff, 2009). Formative assessments of ICC must employ multiple methods and approaches to provide feedback to learners (Deardorff, 2006). However, research on ICC assessment of MFL in the local context seems to be lacking. The current assessment modes frequently used in higher education are teacher assessment and peer assessment with oral questioning as well as correcting errors and giving feedback (Swaran Singh, Lebar, Kepol, Abdul Rahman, \& Muhammad Mukhtar, 2017). Although some HEIs indicated 5\% to $15 \%$ of assessment in MFL courses were on cultural knowledge, there was none on ICC (Hoe, 2016). Hence, there is a need to design formative assessment tools as there does not seem to be any ICC assessment for MFL learners (Fan, 2014; Hoe, 2016). In addition, the ICC level among the local MFL learners in HEIs could be determined.

In this study a set of formative assessments to provide feedback on learners' ICC development was created. An HEI which implemented ICC in the MFL course was selected for implementation. The curriculum documents for MFL courses in polytechnics indicate that students are required to acquire basic communicative skills in Mandarin, and insights into Chinese culture (Department of Polytechnic Education, 2014). However, reports from the minutes of the Continuous Quality Improvement Meetings of the HEI showed that the MFL course assessments focused on linguistic skills and neglected the cultural and intercultural aspects. Hence, there was a need to incorporate ICC assessment in the elementary level MFL course in polytechnics using the CIMFL module.

\section{INTERCULTURAL COMMUNICATIVE COMPETENCE (ICC)}

The communicative competence approach, which focuses on oral communication skills (Bachman, 1990; Chomsky, 1965), is 
critiqued for being superficial and restrictive as it was not open to speakers from different cultures and was unsuitable for multilingual and multicultural societies (Byram, 1997; Lussier, 2011). Communication can only be enhanced when one is familiar with the culture of the language.

ICC is the ability to communicate effectively and appropriately in intercultural situations (Deardorff, 2006). Effective communication is achieving the goals of communication in the target language's culture (Fantini, 2000; Wang, 2011; Zhao, 2016). Appropriate communication refers to acceptable and expected behaviours perceived by the native speaker in a cultural context (Wang, 2011; Zhao, 2016). ICC can be developed using the intercultural approach, based on learners' intercultural knowledge, skills, attitudes and awareness (Deardorff, 2006; Lussier et al., 2007).

Several models for developing ICC exist. Bennett's (1993) Development Model of Intercultural Sensitivity focuses on ethnocentric and ethnorelative phases that learners undergo, while Kramsch's (1993) Model of ICC applies a critical and pragmatic approach of developing and comparing one's own perceptions of culture (personal perception) with the target culture (cultural reality). However, both these developmental models are unsuitable as development takes too much time. Byram's (1997) ICC model focuses on the domains of knowledge, skills, and attitudes similar to the domains for holistic development in the Malaysian educational philosophy. In addition, this model has been the foundation of other ICC research (Deardorff, 2006; Fantini, 2006). Hence, Bryam's model is deemed suitable for the needs of Malaysian HEIs.

\section{Byram's Model of ICC}

Byram's model has been used for ICC within the field of foreign language education and language curriculum development in several countries (Hoff, 2014). This model influenced the development of the attainment targets and descriptors in the CEFRL (Karabinar \& Guler, 2012).

The five competences (savoirs) for foreign language learning are knowledge, attitudes, skills of interpreting and relating, skills of discovery and interaction, and critical cultural awareness (Vos, 
2018). Knowledge refers to knowledge of cultural products and practices, recognition of diversity in the ways of living, and the socio-cultural context of the target culture (Byram, 1997; Lussier et al., 2007). Attitudes are the ability and readiness to view other cultures compared to one's own from different perspectives, with curiosity and openness (Deardorff, 2006). Skills are the ability to use a variety of language strategies to adjust to different contexts and communicate with people from other cultures (Lussier et al., 2007). Specifically, the skills of interpreting and relating refer to the ability to identify ethnocentric perspectives which may cause misunderstanding in intercultural interaction and hence avoid conflict, while the skills of discovery and interaction involve the ability to identify the significance, connotations, similarities and differences in verbal and non-verbal interactions between the target culture and learners' own culture (Deardorff, 2006). Critical cultural awareness is evaluating or judging learners' culture against other cultures and being able to mediate in the intercultural interaction and maintain one's position with a degree of acceptance and rational perspective (Byram, 1997). These five competences are intertwined and may not be easily separated.

\section{Formative Assessment of ICC}

Formative assessment provides feedback which can provide insights into students' interpretations and perspectives of culture. Cultural elements are difficult to assess objectively (Kramsch, 1991). Hence, ICC assessment needs to be flexible to obtain feedback on cultural issues (Paige, Jorstad, Siaya, Klein, \& Colby, 2003).

Formative assessment can be done either in the classroom or as fieldwork, and may be conducted during pre-instructional activities, presentation of content and learner participation as part of an instructional strategy (Dick, Carey, \& Carey, 2014). Assessment is aimed at obtaining feedback from the product, process and progress of learning (Dick et al., 2014). While products and processes can be assessed through interactions and joint evaluations with learner and institutions using problem tasks, performance tasks and evaluation of procedure and skills, learner progress is assessed through reflective tasks (Dick et al., 2014). In addition, the holistic skills and competences of ICC develop over time. Hence, formative 
assessment is suitable for measuring learners' ICC progress (Fantini, 2009) using rubrics and portfolios for a collaborative assessment effort (Dick et al., 2014).

Formative assessment for ICC can be done for the five savoirs. For knowledge, which comprises verbal information and involves cues to recall and sequencing strategy, direct testing is recommended for assessment (Dick et al., 2014; Lussier et al., 2007). Traditional tests such as closed-and open-ended questions, matching items, true/false questions, multiple-choice questions, crossword puzzles, contests and quizzes are suitable (Fantini, 2009).

For attitude, self-evaluation and surveys are recommended (Lussier et al., 2007). Feelings, behaviours and cognitive processes are assessed through perception questionnaires and hypothetical situations for intellectual and motor skills which exhibit specific behaviours (Dick et al., 2014). Learners could be assessed on their change in attitude, such as openness, respect for cultures or tolerance of cultural differences using portfolios (Byram et al., 2002, Deardorff, 2006). A portfolio is useful for self-assessment and for recording learning experiences to make learners conscious of the abilities acquired and their learning process.

The next two savoirs, the skills of interpreting and relating, and discovery and interaction, require tasks that measure performance under specific conditions (Lussier et al., 2007). The assessment would require less of memory but more of skills used to implement tasks under the respective conditions (Dick et al., 2014). The concepts and relationships, steps and procedures are important in this assessment. The skills and ability to synthesise and apply can be assessed via discrete assessment during the learners' demonstration of the skill (Fantini, 2009). Oral and written activities, individual and interactive activities in pairs or groups, dialogues, interviews, discussions, demonstrations, role-plays, and simulations are some forms of assessment which can be used (Fantini, 2009).

Finally, for critical cultural awareness, standards on the judgment of the learners' own culture and other cultures, and the degree of acceptance in order to mediate in the intercultural communication 
needs to be set. Formative assessment can be done using a set of rubrics to measure the standards specified (Dick et al., 2014).

The learners' cultural interpretation is a challenge when assessing ICC in foreign language, so a variety of ongoing formative assessments conducted at different times is required (Lussier et al., 2007). ICC assessment should be a record of the holistic judgment of learners' performance in the different profiles of performance or competence for learners' self-reflection and improvement (Lussier et al., 2007). Hence, measures in the different dimensions of ICC assessment using journals, portfolio assessment and rubrics are recommended (Lussier et al., 2007). However, it is crucial to choose the correct format that best aligns with the assessment objective (Fantini, 2009).

ICC has been assessed in different content and subject areas. Wang's (2011) cultural teaching experiment in an English class at a Chinese college attempted to measure students' ICC before and after the cultural teaching experiment using the Culture Test Model (Valette, 1997) and Social-cultural Test (Wang, 2005). An ICC Test was developed to investigate ICC in terms of intercultural knowledge, skills and attitudes, among 185 international students in a Chinese university (Bai, 2016). In addition, the ICC level of 205 Englishmajor students from a Chinese university was measured using the ICC Self-Report Scale (ICCSRS) (Wang, 2016). However, these tests were summative assessments, catered to specific contexts in China, and did not provide feedback on the progress and process of ICC development among learners. Formative assessment tools which could provide feedback for improving learners' ICC development and catering to the Malaysian context need to be developed for MFL learners in local HEIs.

\section{METHOD}

This study is part of a design and developmental research (DDR). A DDR approach is most suitable for solving instructional problems as the researcher can collaborate with experts and practitioners in designing the module, and this could be used to determine insights into its usability (Mohamed Fauzi \& Raja Hussain, 2016). The 
CIMFL module was designed with formative assessment tools for ICC among elementary MFL learners in Malaysian polytechnics, and was implemented over 12 weeks. This study focused on the implementation of the formative assessments.

\section{Participants}

The volunteer participants were 31 students, aged between 18 and 20 years, taking an elective elementary MFL class at a selected polytechnic. These students were enrolled in a Diploma in Finance and Banking programme. All were Malay students (23 females and 8 males) with no Mandarin language background. However, some students had learned basic Arabic whilst taking Islamic studies classes in school. They had some social interaction with the Chinese community, mainly using Malay or English, but spoke regional Malay dialects (from the states of Kedah, Kelantan, Perak, Penang, Terengganu and Sarawak) among their family members.

\section{The Design of ICC Formative Assessment}

The CIMFL module consisted of the topics Greetings, Making Acquaintances, Numbers, and Dates. Formative assessment was designed using different tools to measure the different competences according to the ICC model (Byram, 1997) (see Table 1). Some of the tools measured the same intercultural competences and learning outcomes as a multi-method and multi-perspective assessment approach could ensure validity and reliability for a better measure of ICC (Deardorff, 2009).

Table 1

Formative Assessment Tools for ICC

\begin{tabular}{|c|c|c|c|c|c|c|}
\hline Tool & & Knowledge & Attitude & Skills & Awareness & Description \\
\hline \multirow[t]{3}{*}{1.} & Intercultural & & & & & Reflective \\
\hline & Discussion and & & & & & activities \\
\hline & Reflection (IDR) & Yes & Yes & Yes & Yes & $\begin{array}{l}\text { for feed- } \\
\text { back }\end{array}$ \\
\hline
\end{tabular}




\begin{tabular}{|c|c|c|c|c|c|c|}
\hline Tool & & Knowledge & Attitude & Skills & Awareness & Description \\
\hline 2. & $\begin{array}{l}\text { Cultural Quizzes } \\
\text { (CQ) }\end{array}$ & Yes & & & & $\begin{array}{l}\text { True-false } \\
\text { quizzes ( } 4 \\
\text { sets) }\end{array}$ \\
\hline 3. & $\begin{array}{l}\text { Cultural } \\
\text { Discovery (CD) }\end{array}$ & & Yes & Yes & Yes & $\begin{array}{l}\text { Structured } \\
\text { ques- } \\
\text { tions, and } \\
\text { research } \\
\text { method; } \\
\text { face- } \\
\text { to-face } \\
\text { discussion } \\
\text { \& discus- } \\
\text { sion forum } \\
\text { activity }\end{array}$ \\
\hline 4. & $\begin{array}{l}\text { Intercultural } \\
\text { Communicative } \\
\text { Task (ICCT) }\end{array}$ & Yes & Yes & Yes & Yes & $\begin{array}{l}\text { Authentic } \\
\text { tasks, } \\
\text { involving } \\
\text { observation } \\
\text { and self- } \\
\text { reflective } \\
\text { feedback } \\
\text { report; } \\
\text { after class } \\
\text { activity }\end{array}$ \\
\hline
\end{tabular}

The Rubrics for Assessing ICC (RAICC) (Lussier et al., 2007) was used to establish the attainment targets for the level of ICC (low, medium and high) among learners. These rubrics provided descriptors and performance criteria for learners' knowledge, attitude, and skills awareness (see Appendix).

\section{Intercultural Discussion and Reflection (IDR)}

IDR activities assessed the knowledge, attitude, skills and awareness among learners. There were seven worksheet activities for learners to write their reflections. They were then assessed according to the rubric for their level of ICC. A sample of questions the IDR for each competence is shown in Table 2. 
Table 2

Selected Questions from IDR Topic 1: Greetings

\begin{tabular}{lll}
\hline Intercultural Discussion \& Reflection Questions & ICC \\
\hline In your culture, how do you make first acquaintance & \\
in informal situations? (Asking name, giving one's & \\
$1 . \quad$ name, and conversation topics for small talk) & Knowledge
\end{tabular}

How is making first acquaintance in informal situa-

2. tions in your culture different from Chinese culture? (Do you touch upon someone's privacy such as age, Skills job, marital status, etc.).

How do you respond when you first meet a Chinese

3. friend and he/she asks you about "How old are you?" "Are you married?" and "Where do you live?" In your opinion, why did he/she ask you such questions?

Awareness

Are you interested in making acquaintance (in infor-

4. mal situations) with Chinese people?

Attitude

Are you aware of the different meanings and expres-

5. sions used in making first acquaintance (in informal situations) in Chinese culture? Please elaborate.

Awareness

\section{Cultural Discovery (CD)}

CD activities assessed students' intercultural skills, attitudes and awareness. Activities enabled learners to discover the Chinese culture as well as their own and other local cultures. The six activities designed included role play, paired discussion and online discussion (see Table 3). Online discussion involved tasks such as searching for information before conducting an online forum discussion in the e-learning portal, CIDOS. Teacher feedback was provided during class discussion or through the e-learning portal after the activities. 
Table 3

Cultural Discovery

\begin{tabular}{|c|c|c|c|}
\hline $\begin{array}{l}\text { Cultural } \\
\text { Discovery }\end{array}$ & Description of Activity & $\begin{array}{l}\text { Activity } \\
\text { Type }\end{array}$ & ICC Assessed \\
\hline $\begin{array}{l}\text { CD } 1 \\
\text { (In class) }\end{array}$ & $\begin{array}{l}\text { Describe and } \\
\text { demonstrate non-verbal } \\
\text { communication behaviour } \\
\text { in greetings in Malaysian } \\
\text { culture. }\end{array}$ & Role play & $\begin{array}{l}\text { Skills } \\
\text { (interpret and } \\
\text { relate) }\end{array}$ \\
\hline $\begin{array}{l}\text { CD } 2 \\
\text { (After class) }\end{array}$ & $\begin{array}{l}\text { You are going to buy } \\
\text { a birthday gift for your } \\
\text { Chinese friend. What } \\
\text { kind of items should be } \\
\text { avoided as gifts for the } \\
\text { Chinese? Why should } \\
\text { you avoid giving such } \\
\text { items as gifts? What are } \\
\text { the gifts taboos in your } \\
\text { own culture? Why? Find } \\
\text { the answers from the } \\
\text { Internet, Chinese friends } \\
\text { or other sources. }\end{array}$ & $\begin{array}{l}\text { Online Dis- } \\
\text { cussion Fo- } \\
\text { rum, Search } \\
\text { Websites }\end{array}$ & $\begin{array}{l}\text { Awareness, } \\
\text { Skills }\end{array}$ \\
\hline $\begin{array}{l}\text { CD } 3 \\
\text { (In class) }\end{array}$ & $\begin{array}{l}\text { Complete the table by } \\
\text { stating the kinship titles } \\
\text { in Chinese culture and } \\
\text { your own culture. Tell } \\
\text { the differences between } \\
\text { two cultures in terms of } \\
\text { kinship titles. }\end{array}$ & $\begin{array}{l}\text { Paired dis- } \\
\text { cussion }\end{array}$ & $\begin{array}{l}\text { Skills, } \\
\text { Attitude }\end{array}$ \\
\hline $\begin{array}{l}\text { CD } 4 \\
\text { (In class) }\end{array}$ & $\begin{array}{l}\text { Identify the auspicious } \\
\text { and inauspicious numbers } \\
\text { in Chinese culture based } \\
\text { on the situations given. }\end{array}$ & $\begin{array}{l}\text { Paired dis- } \\
\text { cussion }\end{array}$ & $\begin{array}{l}\text { Skills, } \\
\text { Awareness }\end{array}$ \\
\hline
\end{tabular}

Cultural Quizzes (CQ)

Cultural quizzes assessed students' understanding of Chinese culture and intercultural knowledge. There were four quizzes with 
true-false items (see Table 4 for sample items in a cultural quiz with the reference to the relevant cultural learning outcome). Each quiz had a total of 10 marks.

Table 4

\section{Sample of Items in a Cultural Quiz}

\begin{tabular}{|c|c|c|}
\hline No. & $\begin{array}{l}\text { Please state TRUE or FALSE after each } \\
\text { statement. }\end{array}$ & $\begin{array}{l}\text { Reference to } \\
\text { learning outcome }\end{array}$ \\
\hline 1. & Chinese surname refers to the father's name. & 2.1.1 \\
\hline 2. & Chinese surname comes after the given name. & 2.1.1 \\
\hline 3. & $\begin{array}{l}\text { The majority of Chinese given names consist of } \\
\text { two characters. }\end{array}$ & 2.1 .2 \\
\hline 4. & $\begin{array}{l}\text { Chinese women adopt the husband's family name } \\
\text { (surname) when they get married. }\end{array}$ & 2.1.1 \\
\hline 5. & $\begin{array}{l}\text { Some Chinese families share one same character } \\
\text { in their given names among all male or female } \\
\text { members (siblings, cousins, nephews) of a par- } \\
\text { ticular generation. }\end{array}$ & 2.1.1 \\
\hline 6. & $\begin{array}{l}\text { In Chinese culture, normally only the given name } \\
\text { is provided when introducing in first meetings in } \\
\text { an informal situation. }\end{array}$ & 2.1 .2 \\
\hline 7. & $\begin{array}{l}\text { In Chinese culture, while making first acquain- } \\
\text { tance in an informal situation, it is impolite to } \\
\text { ask personal questions such as marital status, } \\
\text { children, family, age, income, job, etc. }\end{array}$ & 2.1.3 \\
\hline 8. & $\begin{array}{l}\text { In formal situations, the Chinese address some- } \\
\text { one by his/her surname. }\end{array}$ & 2.1 .4 \\
\hline 9. & $\begin{array}{l}\text { In Chinese culture, visitors seldom bring a gift } \\
\text { for the host during visits. }\end{array}$ & 2.2 .4 \\
\hline 10. & $\begin{array}{l}\text { The Chinese will open the gift after receiving it } \\
\text { to show appreciation. }\end{array}$ & 2.2 .4 \\
\hline 11. & $\begin{array}{l}\text { The Chinese usually decline offers (such as food } \\
\text { or drinks) by others for one or two times before } \\
\text { they accept it. }\end{array}$ & 2.2 .4 \\
\hline
\end{tabular}




\section{Intercultural Communicative Task (ICCT)}

The ICCT was a holistic assessment of ICC as it involved a discovery task in an authentic cultural context where learners were assessed on a visit to a Chinese friend's home. Learners experienced the target language cultural practices and applied ICC in a real-world setting. The ICCT was implemented at the end of the module as a group task for four to five learners. There were three stages: (1) pre-task, (2) task-in-progress and (3) post-task.

Pre-task activities allowed learners to prepare and practice the conversation for the visit, to decide on an appropriate gift for the host and other arrangements. The task-in-progress involved the learner's visit to the Chinese friend's home and the practice of appropriate language and non-linguistic behaviour that did not conflict with the target culture. It included visiting etiquette, responding to compliments and offering gifts. The language used could include that from the topic of greetings, making introduction among family members, enquiring about Chinese cultural festivals, Chinese zodiac, favourite numbers, and exchange of contact numbers. Learners were required to video record the task-in-progress. During the post-task, each group had to prepare and submit their report, reflection and feedback with the video recording of the visit.

\section{Validity and Reliability}

A qualitative measurement of the validity of the four formative assessment tools was carried out before implementation, based on interviews with external experts who had extensive experience in quality improvement for assessment in MFL. The formative assessment reliability could also be established through this validation process, and through the "inquiry audit" process (Lincoln \& Guba, 1985; Patton, 2001). The two experts were briefed on Deardorff's (2009) assessment criteria for ICC, and the purpose of the study (Yusof, Awang Hashim, \& Chan, 2016). They gave their informed perspective and feedback on the best practices based on the evaluation checklist (Deardorff, 2009). The checklist included alignment with intercultural competence outcomes, appropriateness of assessment tools in collecting evidence of learning, and the adequacy of processes and timelines planned for the assessment throughout the course. 
Expert feedback confirmed that the formative assessment was associated with ICC outcomes (Byram, 1997) and that the multiple assessment methods would be a reliable measure for assessing learners' ICC. One expert however reminded that the language learning outcomes, which was the core aspect of the course, should not be neglected in the assessment. Hence, the formative assessment tools in the present study included assessment of language competency as well as the cultural aspect of MFL.

\section{Implementation Procedures}

After validation, the assessment was implemented. The IDR (Intercultural Discussion and Reflection) was conducted in class, during which learners discussed with peers and wrote and submitted their reflective feedback. Three CD (Cultural Discovery) activities were also implemented during class where learners answered questions in the worksheets. Three other activities were online discussions after class. CQ were true/false questions which were answered in class immediately after topic completion. The ICCT was conducted at the end of module, involving a visit to a Chinese friend's home after completion of the related topics. The responses were evaluated and scored.

\section{Data Collection and Analysis}

The scores derived from the implementation of the four formative assessment tools were standardised and analysed based on the RAICC (Lussier et al., 2007). Learners' level of ICC could be determined and defined as low (1-3 points), medium (4-7 points) or high (8-10 points) based on the rubric. The percentage of students achieving high, medium and low scores for each activity was determined.

\section{DISCUSSION}

The learners' ICC achievement in the formative assessments are reported according to the four competences: knowledge, skills, attitudes and awareness (see Table 5). The findings indicate that IDR and CQ contributed to high scores in knowledge (80.6\% and 93.5\% respectively), while CD contributed to the attainment of high scores in skills (100\%). CD contributed to much higher scores in attitudes and awareness (90.3\% and $100 \%$ respectively). 
Table 5

Percentage of Achievement in ICC Formative Assessments for Intercultural Knowledge, Skills, Attitudes and Awareness

\begin{tabular}{lccccccccccccc}
\hline & \multicolumn{3}{c}{ Knowledge } & \multicolumn{3}{c}{ Skills } & \multicolumn{3}{c}{ Attitudes } & \multicolumn{3}{c}{ Awareness } \\
\hline ICC & IDR & CD & CQ & IDR & CD & CQ & IDR & CD & CQ & IDR & CD & CQ \\
\hline High & $80.6 \%$ & - & $93.5 \%$ & - & $100 \%$ & - & $67.7 \%$ & $90.3 \%$ & - & $38.7 \%$ & $100 \%$ & - \\
Medium & $19.4 \%$ & - & $6.5 \%$ & $96.8 \%$ & - & - & $32.3 \%$ & $9.7 \%$ & - & $61.3 \%$ & - & - \\
Low & - & - & - & $3.2 \%$ & - & - & - & - & - & - & - & - \\
\hline
\end{tabular}

Analysis of the IDR results showed that most learners acquired high ICC in intercultural knowledge and attitudes but were low in terms of skills and awareness. As for CQ, learners had high scores for intercultural knowledge. However, for $\mathrm{CD}$, although there was no analysis of the knowledge component, learners had higher scores for skills, attitudes and awareness. They could apply the appropriate intercultural competence while discovering the target culture and their own and other local cultures, as reflected in the six activities. The higher CD scores might have been due to the heightened interest and positive learner attitudes when discovering cultures, besides effective task design for measuring ICC.

Table 6

Learners' Achievement in the Intercultural Communicative Task (ICCT)

\begin{tabular}{lcccc}
\hline \multicolumn{5}{c}{ Intercultural Communicative Task (ICCT) } \\
\hline Knowledge & Skills & Attitudes & Awareness \\
\hline Group 1 & 9 & 9 & 9 & 8 \\
Group 2 & 9 & 9 & 9 & 8 \\
Group 3 & 9 & 9 & 8 & 8 \\
\hline
\end{tabular}

Only three groups completed the ICCT. Other groups were unable to accomplish the task as some group members withdrew due to time constraints, since it was held at the end of the semester when learners were busy with their final projects. The findings from the group's task report and reflection and the video recordings were 
analysed thematically. Analysis of the ICCT scores for intercultural knowledge, skills, attitudes and awareness showed that all three participating groups demonstrated a high level of ICC (See Table 6).

The following analysis of the journal records and video recordings of the ICCT is reported according to the competences.

\section{Intercultural knowledge and skills}

Learners mentioned that they became aware of and acquired knowledge on the differences in greetings between Chinese and Malay cultures during the task. All the groups pointed out that Chinese adopted the modern form of greeting by shaking hands, as in the western culture. However, the Malay culture did not allow body contact between different genders during greetings (such as touching both hands or touching the cheeks), except among their kin. Group 3 revealed that Malays still practiced the traditional culture in greetings.

Due to the differences in greetings between these two cultures, the learners adopted smiles and gestures such as nodding the head for greetings, as observed in learners' video records. This was the development of an intermediate culture between the two distinct cultures. The video records submitted by the groups showed that learners developed intercultural knowledge and skills, as they were able to analyse the cultural differences in terms of non-verbal behaviour against their own experience from the intercultural point of view (Lussier et al., 2007). In addition, they correctly interpreted paralinguistic and non-verbal behaviour (Byram, 1997). They were also able to express insights into their own culture's rules on how greetings were offered (Bennett, 2008). Nodding the head for communicating was a shared understanding negotiated based on the differences (Bernett, 2008).

Group 2 related the role of numbers in Chinese culture. The Chinese adopted auspicious numbers and avoided inauspicious ones, which they noted when asking for phone numbers for the planned visit. Group 1 also noted that there should be awareness that the number four was taboo among the Chinese community due to the homophone 
of 'four' (sǐ) and 'dead' (sì) in Chinese language and the belief that bad things would happen if the number was adopted. Learners could state that there was no such belief in their own culture. Hence, learners were aware of the taboos in routine situations for ICC knowledge (Byram, 1997).

\section{Attitudes}

Learners began to develop positive attitudes in relation to their cultural experience. Group 1 enjoyed the Chinese tea served by the host during the visit. It was their first taste of this tea and this drew comparison with the Malay culture where a sweet rose syrup was normally served for guests. Learners developed a high intercultural attitude as they enjoy observing and participating in the intercultural exchange (Lussier et al., 2007). Values such as openness to the customs, taboos and beliefs of other cultures were mentioned by Group 2: "We respect all cultures. To know the customs, taboos of each culture is to avoid problems between cultures. We may also assist in solving problems to respond to urgent matters." A positive willingness to adapt to the target culture was noted by Group 3: "Yes, we will adapt ourselves and accommodate to Chinese culture, study about the culture."

Hence, the ICCT could develop ICC attitudes as learners showed interest in discovering the practices of other cultures, and displayed willingness to seek opportunities to engage with others (Byram, 1997). The coexistence of different cultural practices and customs, without religious conflicts, was due to cultural understanding. As noted by Group 3:

\section{Most of the practices and customs for the two cultures are concomitant/ correspond, and therefore the practices of both races and culture can respect, understand and learn the customs, culture and practices because they are not conflicting with our religions.}

At the end of the task, Group 2 pointed out that the task stimulated their consciousness about their own culture. They admitted that they were unsure about their own culture in some respects, such as the 
months in the Muslim traditional calendar and would improve their cultural knowledge of the history and customs of their own culture. Hence, this encouraged them to study their own culture. As Group 2 reported:

I am thinking of my own culture, there are many aspects in my own culture that I still don't know. When the teacher tells about the Chinese culture, I was called to reflect on our own culture.

This suggests that ICCT could encourage learners to be proactive and show interest in discovering practices and phenomena within their own culture.

\section{Awareness}

ICCT can develop learners' intercultural awareness. Group 1 mentioned "Everyone should be sensitive towards other races in order to cultivate the harmony of the nation, society and neighbourhood." Learners believed misunderstanding and confusion may occur due to the different dialects within both the Malay and Chinese languages.

Misunderstanding may happen due to the difference in meaning in different dialects and cultures. Chinese not only speak Mandarin but also dialects such as Hakka, Cantonese, Hainan, and others. For Malay language, there were dialects from different states which may not be the same as the standard Malay language. This may cause some problems. We need to ask when we do not understand to avoid misunderstanding.

Group 3 reported that they respected Chinese religious practices although these were unfamiliar and in conflict with their own religious beliefs: "We saw the Chinese altar and ritual materials in the living hall which were unfamiliar to us, but we showed respect although it was against our religion."

Learners possessed the cultural awareness as they were able to foresee and handle the potential conflicts, which showed acceptance of differences. 


\section{CONCLUSIONS}

The ICC formative assessment tools used in the CIMFL module could be used for developing ICC. High levels of ICC knowledge were developed using IDR and CQ, while high levels of ICC skills, attitudes and awareness were developed when using CD activities. This finding is similar to previous research which showed that traditional tests and quizzes were suitable for assessing knowledge (Dick et al., 2014; Lussier et al., 2007), and that hypothetical situations such as role plays and discussions (both face to face and online) enabled development of attitudes, skills and awareness (Dick et al., 2014). The CD tasks such as 'buying a birthday gift for your Chinese friend' allowed them to search for information and evaluate the possibility of gifts to avoid. Discovering new cultural information and making judgments developed high ICC attitudes, skills and awareness.

The ICCT developed high scores in all the domains. A holistic assessment task which allowed learners to discover culture in a real experience developed high levels of ICC (Fantini, 2009). The journal notes and videos compiled in a portfolio for the ICCT were evaluated based on the rubrics. Excerpts from these artefacts, as discussed earlier, indicated high levels of ICC competences. Hence, a holistic assessment task such as ICCT should be provided for developing ICC.

Lecturers teaching tertiary level MFL should consider a variety of assessments, not just formal assessment. In fact, informal assessments such as the ICCT and project-based learning seem to have potential in developing ICC in MFL. Similar formative assessment tasks are recommended in teaching other languages, not only in HEIs but at different levels of education. Hence, further empirical research could be done to investigate the effectiveness of these assessment tools for different languages and at different education levels.

Byram's ICC model is particularly important in a multiracial and multicultural society such as Malaysia. Acquiring a language requires more than just communication competence. Due to the diversity of Malaysian society, there is also a need to develop knowledge, awareness, skills and positive attitudes towards the different cultures in the country. In essence, Malaysians of all ethnicities should have a 
level of ICC sufficient to make judgments and comparisons between their own individual culture and the culture of other races so as to develop a Malaysian ICC. This would enable different cultural groups to continue to live together in racial and cultural harmony.

\section{ACKNOWLEDGEMENT}

This research received no specific grant from any funding agency in the public, commercial, or not-for profit sectors.

\section{REFERENCES}

American Council on the Teaching of Foreign Languages. (2017). NCSSFL-ACTFL global can-do statement: Performance indicators for language learners. Retrieved from https:// www.actfl.org/sites/default/files/CanDos/ Intercultural \%20 Can-Do_Statements.pdf

Bachman, L. F. (1990). Fundamental considerations in language testing. Oxford, UK: Oxford University Press.

Bai, X. F. (2016). 在华留学生跨文化交际能力测试与分析一以南 京地区部分高校留学生为样本. [Assessment and analysis of intercultural communicative competence among international students in China-Based on samples of international students in Nanjing] (Unpublished master's thesis). Nanjing Normal University, China. Retrieved from http://oversea.cnki.net/ $\mathrm{kcms} /$ detail/detail aspx ?recid $=\&$ FileName $=1016304181$. nh $\&$ DbName $=$ CMFD2017 $\&$ DbCode $=$ CMFD

Bennett, M. J. (1993). Towards ethnorelativism: A developmental model of intercultural sensitivity. In M. R. Paige (Ed.), Education for the intercultural experience, 21-71. Yarmouth, ME: Intercultural Press.

Byram, M. (1997). Teaching and assessing intercultural competence. Clevedon, UK: Multilingual Matters.

Byram, M., Gribkova, B., \& Starkey, H. (2002). Developing the intercultural dimension in language teaching: A practical introduction for teachers. Language Policy Division, Directorate of School, Out-of-School and Higher Education, Council of Europe, Strasbourg. Retrieved from http://www. coe.int/t/dg4/linguistic /Source/ Guide_dimintercult_EN.pdf 
Chan, S. F., DeWitt, D., Chin, H. L. (2018). The analysis of cultural and intercultural elements in Mandarin as a Foreign Language textbooks from selected Malaysian higher education institutes. Malaysian Online Journal of Educational Sciences (MOJES), 6(1), 66-90. Retrieved from http://mojes.um.edu.my/index. php/MOJES/article/view/12512

Chomsky, N. (1965). Aspects of the theory of syntax. Cambridge, MA: The MIT Press. Retrieved from https://faculty. georgetown.edu/irvinem/theory/Chomsky-Aspects-excerpt. pdf

Council of Europe. (2017). Common European framework of reference for languages: Learning, teaching, assessment companion volume with new descriptors. Cambridge, UK: Cambridge University Press.

Deardorff, D. K. (2006). Identification and assessment of intercultural competence as a student outcome of internationalization. Journal of Studies in International Education, 10(3), 241266.

Deardorff, D. K. (2009). Implementing intercultural competence assessment. In D. K. Deardorff (Ed.), The SAGE handbook of intercultural competence (pp. 477-491). Thousand Oaks, CA: S.

Department of Polytechnic Education, Ministry of Higher Education Malaysia. (2014). Syllabus: Mandarin 1, DUF1022.

Department of Statistics Malaysia. (2017). Press release: Current population estimates 2016-2017. Putrajaya, Malaysia: Department of Statistics Malaysia Retrieved from https:// www.dosm.gov.my/v1/index.php?r=column/pdfPrev\&id=a1 d1UTFZazd5ajJiRWFHNDduOXFFQT09

Dick, W., Carey, L. \& Carey, J. O. (2014). The systematic design of instruction. Essex, UK: Pearson.

Fan, P. S. (2014). 马来西亚国立大学华语课本中华文化因素研 究初探 [A preliminary study of Chinese cultural factors in Chinese textbooks of National University of Malaysia]. In Proceeding of the Sixteenth Korea-China Education and Culture Forum, 77-84.

Fantini, A. E. (2000). A central concern: Developing intercultural competence. In SIT Occasional Papers Series: Addressing intercultural education, training and service, 25-42. School for International Training. Vermont, USA. Retrieved from http://www.sit.edu/SITOccasionalPapers/sitops01.pdf 
Fantini, A. E., \& Tirmizi A. (2006). Exploring and assessing intercultural competence. SIT Graduate Institute/SIT Study Abroad, Digital Collections @ SIT. World Learning Publication. Retrieved from http://digitalcollections.sit.edu/ cgi/viewcontent.cgi article $=1001 \&$ context=worldlearning publications.

Hoe, F. T. (2014). 马来西亚国立大学华语课程教材的研究. [A study of Malaysian national universities Mandarin courses teaching materials.] Chinese Education, 01. Retrieved from http://oversea. cnki.net/kcms/detail/detail.aspx?filename=HWHW201401011\& dbcode $=$ CJFD\&dbname $=$ CJFD2014

Hoe, F. T. (2016). 马来西亚国立大学华语课程中的文化教学. [The teaching of culture in Mandarin courses in Malaysia public universities]. Paper presented at the International Conference on Teaching Mandarin as a Second Language in Malaysia 2016, Kongzi Institute, University of Malaya.

Hoff, H. E. (2014). A critical discussion of Byram's model of intercultural communicative competence in the light of building theories. Intercultural Education, 25(6), 508-517. Retrieved from https://doi.org/10.1080/14675986.2014.9921 12

Hou-Keat, K., Nurul Husna Hassan, \& Norasrani Ramli. (2017). Motivation and gender differences in learning Spanish as a foreign language in a Malaysian technical university. Malaysian Journal of Learning and Instruction, 14(2), 59-83.

Jin, T. (2013). Intercultural competence in the learning of Chinese as a foreign language in the UK: An exploratory study. In M. Xing \& M. Li (Eds.), Developing pedagogies for teaching Chinese as a foreign language in higher education (Applied Chinese Language Studies IV) (pp. 15-29). London, UK: Sinolingua London.

Karabinar, S., \& Guler, C. Y. (2012). The attitudes of EFL teachers towards teaching culture and their classroom practices. Journal of Educational and Social Research, 2(2), 113-126. doi: 10.5901/jesr.2012.v2n2.113

Kramsch, C. (1991). Culture in language learning: A view from the U.S. In K. de Bot, R. B. Ginsberg, \& C. Kramsch, (Eds.), Foreign language research in cross-cultural perspectives, 217-240. Philadephia, PA: John Benjamins. 
Kramsch, C. (1993). Context and culture in language teaching. Oxford, UK: Oxford University Press.

Lesencius, A., Draghici, C., \& Nagy, D. (2011). Models of forming: Developing the intercultural communication competence. models relevant to the Romanian Military Higher Education. Intercultural Communication, 43-51. Retrieved form http:// www.aos.sk/casopisy/science/dokumenty/ archiv/2011_1/ cl7.pdf

Liddicoat, A. J. (2001). Static and dynamic view of culture and intercultural language acquisition. New Zealand Language Teacher, 27, 47-58. Retrieved from https://cdn.auckland. ac.nz/assets/education/about/centres/lipis/docs/readings/ liddicoat.pdf

Lincoln, Y. S., \& Guba, E. G. (1985). Naturalistic inquiry. Beverly Hills, CA: Sage.

Lussier, D. (2011). Language, thought and culture: Links to intercultural communicative competence. Canadian and International Education / Education Canadienne et Internationale, 40(2), 34-60. Retrieved from http://ir.lib.uwo. $\mathrm{ca} /$ cie-eci/vol40/iss $2 / 4$

Lussier, D., Kostova, S. C., Golubina, K., Ivanus, D., Skopinskaja, L., Retamar, R., \& Wiesinger, S. (2007). Guidelines for the assessment of intercultural communicative competence. In I. Lazar, M. Huber-Kriegler, D. Lussier, D., G. S Matei, \& C. Peck (Eds.), Developing and accessing Intercultural Communicative Competence: A guide for language teachers and teacher educators, 23-39. Retrieved from http://archive. ecml.at/mtp2/publications/B1_ICCinTE_E_internet.pdf

Ministry of Education Malaysia. (2015). Malaysia educational statistics 2015. Putrajaya, Malaysia: Author. Retrieved from https://moe.gov.my/images/Terbitan/Buku-informasi/PerangkaanPendidikan-Malaysia-2015/Perangkaan\%20Pendidikan $\% 20$ Malaysia \%202015.pdf.pdf

Mohamed Fauzi, S. S., \& Raja Hussain, R. M. (2016). Designing instruction for active and reflective learners in the flipped classroom. Malaysian Journal of Learning and Instruction, 13(2), 147-173

Paige, R. M., Jorstad, H., Siaya, L., Klein, F., \& Colby, J. (2003). Culture learning in language education: A review of the literature. In Culture as the core: Perspectives on culture in Second Language Learning, 173-236. Greenwich, CT: 
Information Age.Retrieved from http://carla.umn.edu/culture/ resources/litreview.pdf

Patton, M. Q. (2001). Qualitative evaluation and research methods (3rd ed.). Thousand Oaks, CA: Sage.

Swaran Singh, C. K., Lebar, O., Kepol, N., Abdul Rahman, R., \& Muhammad Mukhtar, K. A. (2017). An observation of classroom assessment practices among lecturers in selected Malaysian higher learning institutions. Malaysian Journal of Learning and Instruction, 14(1), 23-61.

The Office of Chinese Language Council International. (2010). 国际汉语教学通用课程大纲. [International curriculum for Chinese language education] (5th Ed.) Beijing, China: Foreign Language Teaching and Research Press.

Valette, R. M. (1997). Modern language testing. New York, NY: Harcourt Brace Jovanovich.

Vos, L. (2018). Teaching Intercultural Communicative Competence alongside Language Proficiency (Unpublished master's thesis). Utrecht University, Netherlands.

Retrieved from https://dspace.library.uu.nl/handle/1874/360047

Wang, F. F. (2016). A development survey study of English majors' intercultural communicative competence (Unpublished master's thesis). Yangzhou University, China. Retrieved from http://oversea.cnki.net/kcms/ detail/detail.asp $\mathrm{x}$ ?recid $=\&$ FileName $=1016290208$. nh $\&$ DbName $=$ CMFD2017 $\&$ DbCode $=$ CMFD

Wang, W. T. (2011). Cultivation of intercultural communicative competence under the model of affection, cognition and behaviour (Unpublished master's thesis). Taiyuan University of Technology, China. Retrieved from http://oversea.cnki. net $/ \mathrm{kcms} /$ detail/detail.aspx $?$ recid $=\&$ FileName $=1011081409$. nh\&DbName $=$ CMFD2011\&DbCode $=$ CMFD

Wang, Z. Y. (2005). 以跨文化交往为目的的外语教学. [Foreign language teaching for the purpose of intercultural communication]. Beijing, China: Beijing Language and Culture University Press.

Yap, T. T. (2011). 马来西亚高校汉语作为二语教学发展研究. [A study on the development of teaching Chinese as Second Language in Malaysian universities] (Unpublished doctoral thesis). Minzu University of China, Beijing. 
Yusof, N., Awang Hashim, R., \& Chan, K. K. (2016). Investigating learning space for research workspaces in higher education in Malaysia. Malaysian Journal of Learning and Instruction, 13(2), 201-226.

Zhao, M. L. (2016). Intercultural sensitivity and intercultural communicative competence: A study of English majors at two normal universities (Unpublished master's thesis). Yulin Normal University, China. Retrieved from http://oversea.cnki. net $/ \mathrm{kcms} /$ detail $/$ detail.aspx? $\mathrm{recid}=\&$ FileName $=1017021025$. nh\&DbName $=$ CMFD2017 $\&$ DbCode $=$ CMFD 


\section{Appendix}

\section{Summary of RAICC \\ (Lussier et al., 2007)}

\begin{tabular}{|c|c|c|c|}
\hline Levels & Intercultural Knowledge & Intercultural Skills & Intercultural Attitudes \\
\hline High & $\begin{array}{l}\text { Accurate knowledge } \\
\text { of general and specific } \\
\text { cultural elements from } \\
\text { variety of learning } \\
\text { strategies. } \\
\text { Able to explain, comment } \\
\text { and analyse all learned } \\
\text { cultural differences } \\
\text { comparing them in depth } \\
\text { with his own experience } \\
\text { and local and national } \\
\text { traditions. }\end{array}$ & $\begin{array}{l}\text { Can participate in } \\
\text { conversations in } \\
\text { different culturally } \\
\text { determined } \\
\text { situations freely. } \\
\text { Uses appropriate } \\
\text { expressions in } \\
\text { different intercultural } \\
\text { contexts. Clearly } \\
\text { expresses verbal and } \\
\text { non-verbal behavioural } \\
\text { flexibility. }\end{array}$ & $\begin{array}{l}\text { Enjoys observing, } \\
\text { participating, describing, } \\
\text { analysing, and interpreting } \\
\text { intercultural elements and } \\
\text { situations. } \\
\text { Expresses empathy toward } \\
\text { representatives of different } \\
\text { cultures. Manifests respect } \\
\text { for otherness, other beliefs } \\
\text { and values. }\end{array}$ \\
\hline Medium & $\begin{array}{l}\text { Has some concrete } \\
\text { knowledge about cultural } \\
\text { facts and can modify } \\
\text { according to situation. } \\
\text { Can explain different } \\
\text { aspects of culturally } \\
\text { determined acts of } \\
\text { behaviour and compare } \\
\text { with his own experience }\end{array}$ & $\begin{array}{l}\text { Can participate in } \\
\text { conversations more } \\
\text { freely in certain } \\
\text { predetermined } \\
\text { situations. } \\
\text { Able to understand } \\
\text { the variability of } \\
\text { verbal and non-verbal } \\
\text { behaviour within } \\
\text { the target cultural } \\
\text { community but doesn't } \\
\text { try to recreate and } \\
\text { doesn't reflect upon } \\
\text { how the culturally } \\
\text { different person might } \\
\text { be construing events. }\end{array}$ & $\begin{array}{l}\text { "Mixed" attitudes to } \\
\text { culturally determined } \\
\text { acts of behaviour. Accept } \\
\text { intercultural ambiguities } \\
\text { as challenging, showing } \\
\text { openness and interest } \\
\text { towards others. Tends to } \\
\text { see things and situations } \\
\text { from the other's point } \\
\text { of view. Open to other } \\
\text { cultures, accepting and } \\
\text { being sympathetic to other } \\
\text { beliefs and values. }\end{array}$ \\
\hline Low & $\begin{array}{l}\text { Can provide simple } \\
\text { descriptions and identify } \\
\text { limited specific and } \\
\text { general cultural facts. } \\
\text { Can speak generally } \\
\text { about some aspects of } \\
\text { culturally determined acts } \\
\text { of behaviour. Relies on } \\
\text { simple mental checklist } \\
\text { and applies cultural } \\
\text { stereotypes }\end{array}$ & $\begin{array}{l}\text { Can participate in } \\
\text { conversations in } \\
\text { different culturally } \\
\text { determined situations } \\
\text { with some standard } \\
\text { expressions. Does not } \\
\text { analyse or incorporate } \\
\text { cultural variables. }\end{array}$ & $\begin{array}{l}\text { Some sensitivity but } \\
\text { also shows ethnocentric } \\
\text { attitudes and perceptions } \\
\text { and expects adaptation } \\
\text { from others. } \\
\text { Demonstrates a degree of } \\
\text { cultural awareness but still } \\
\text { tends to be influenced by } \\
\text { cultural stereotypes due to } \\
\text { a passive attitude towards } \\
\text { other cultures. }\end{array}$ \\
\hline
\end{tabular}

